\title{
Socio-economic Benefits of Non-timber Forest Products to the AFCOE2M Communities of Southern Cameroon
}

\author{
R. G. Caspa ${ }^{1}$, G. N. Nyambi ${ }^{1}$, Mbang J. Amang ${ }^{1}$, M. N. Mabe ${ }^{1}$, A. B. Nwegueh ${ }^{1} \&$ B. Foahom ${ }^{1}$ \\ ${ }^{1}$ Institute of Agricultural research for Development, Cameroon \\ Correspondence: G. N. Nyambi, Institute of Agricultural research for Development, Cameroon. E-mail: \\ gnyambi@yahoo.com
}

Received: June 8, 2016 Accepted: September 19, 2016 Online Published: May 13, 2020

doi:10.5539/sar.v9n3p30 URL: https://doi.org/10.5539/sar.v9n3p30

\begin{abstract}
A study was carried out in the community forest of Ebo, Medjounou and Mbamesoban communities (AFCOE2M) in the South Region of Cameroon to evaluate the contribution of non-timber forest products (NTFPs) to the people's livelihood.

The study identifies the various NTFPs used and further evaluates their socio-economic and cultural contributions in sustaining the livelihood of the AFCOE2M community. Essentially, the study assesses the exploitation and utilization of NTFPs. One Hundred and twenty five (125) individuals were randomly selected in the three villages that make up the AFCOE2M community forest. Fifty two (52) species of NTFPs of plant origin were identified, from which seven (7) were frequently used in all the three villages namely; Irvingia gabonensis, Trichoscypha acuminata, Alstonia boonei, Garcinia kola, Piper guineense, Picralima nitida, and Ricinodendron heudelotii. Results reveal that NTFPs plant parts used for consumption consist of $68 \%$ fruits, $20 \%$ seeds, $5 \%$ barks, $4 \%$ roots and 3\% leaves. NTFPs used for medicinal purposes comprised of $70 \%$ barks, $16 \%$ seeds, $7 \%$ leaves, $5 \%$ fruits and $2 \%$ roots. There was a significant difference $(\mathrm{P}=0.049)$ in the number of NTFP types consumed as food while that was not the case for medicinal NTFPs $(\mathrm{P}=0.86)$. There was a significant difference in the number of NTFP species used for food originating from different land use types $(\mathrm{P}$-value $=0.048)$ as well as between those used for medicinal purposes $(\mathrm{P}$-value $=0.012)$.
\end{abstract}

Keywords: non-timber forest products, livelihood, local communities, Congo basin forest

\section{Introduction}

Forests provide many useful goods and services of subsistence and commercial values called non-timber forest products (NTFPs). From time immemorial, forest goods other than timber have supplied the basic needs of humankind. These include fruits, roots, seeds, nuts, barks, fungi, resins, feathers, bush meat, fibres and leaves (Nkwatoh et al., 2010; Shanley et al., 2015). NTFPs play a crucial role in the daily lives and welfare of people. They act as sources of food, income, medicine, construction material and fuelwood, as well as resources of spiritual and cultural significance (Aiyeloja and Ajewole, 2006; Hoare, 2007). NTFPs provide nutrients which are usually absent in daily diets such as proteins, vitamins, starch, minerals and other compounds, thus preventing malnutrition (Johns and Sthapit, 2014; Shanley et al., 2015). NTFPs are also important for food security, making a major contribution to food intake of most rural dwellers (Termote et al., 2010; Olaniyi et al., 2013). However, the sustainable management of community forests is crucial to sustain a stable livelihood for the community dwellers.

Sustainable management ensures that forest goods and services meet present needs while ensuring their continued availability to meet long-term needs (Bikoue and Essomba, 2008). According to Caspa et al. (2014; 2015), there has been an increased awareness of NTFPs contribution to household and national economies. The latter authors equally point out the contribution of NTFPs to some environmental objectives such as biodiversity conservation.

African forests are reservoirs of biodiversity and the ecological functions that are essential for humanity. The forest formations play an important role in meeting many basic needs of local people. According to Eyog Matig et al. (2006), they provide wood and energy and contribute to the nutritional needs, especially of the most vulnerable social groups. Similarly, they represent the main source of medicines in rural areas. Given their 
importance to rural communities, local NTFP species in Cameroon deserve more attention in order to optimize the potential they represent. NTFPs are exposed to pressure from logging, slash and burn agriculture, population growth and mining. The consequences include deforestation and degradation of forest ecosystems, significant land use change and poor standards of living for rural populations (Ernest et al. 2010).

Community forests were created to facilitate the participation of local communities in the sustainable and equitable management of natural resources and access to social and economic benefits from these resources. The forest areas of Cameroon have a significant potential for NTFPs worth valuing. Participatory management and development of the NTFPs sector will reduce extreme poverty and hunger while promoting environmental protection (Tchoundjeu et al., 2010). Also, it could improve living conditions of rural communities. So it is important to understand the evolution of a range of issues relating to NTFPs such as their modes of management and the contribution they make to the development of local communities.

NTFPs are harvested from the wild in natural forests (SCBD, 2001; van Andel, 2006) or from wild stock preserved by local farmers on farms in various traditional agroforestry systems (Tabuna, 2000). They are used and managed in complex socio-economic and ecological environments. In traditional forest communities, many NTFPs may be used for subsistence while others are the main or only source of income (Nivedita and Pramod, 2016). Many NTFPs, especially those that are traded in international markets are sometimes cultivated as farm crops, whereas those for local and regional trade are managed in home gardens, fallows and forests (Shackleton, 2004). These complex forest management systems generate dietary variety and reduce environmental risks, thus represent a key adaptation strategy in the face of climate change (Gomez-Baggethun et al., 2013).

The objective of this study is to determine the contribution of NTFPs to the livelihood of AFCOE2M communities.

\section{Materials and Methods}

\subsection{Study Area}

The AFCOE2M community forest is located in the Ambam Sub-Division, Ntem Valley Division in the South Region of Cameroon. It covers 3,155 hectares of land and extends over three villages namely, Mbam-Essaobam, Ebozi II and Medjounou. The area is specifically located between latitude $20^{\circ} 40^{\prime}$ East and longitude $11^{\circ} 58^{\prime}$ West (Amang et al., 2015)

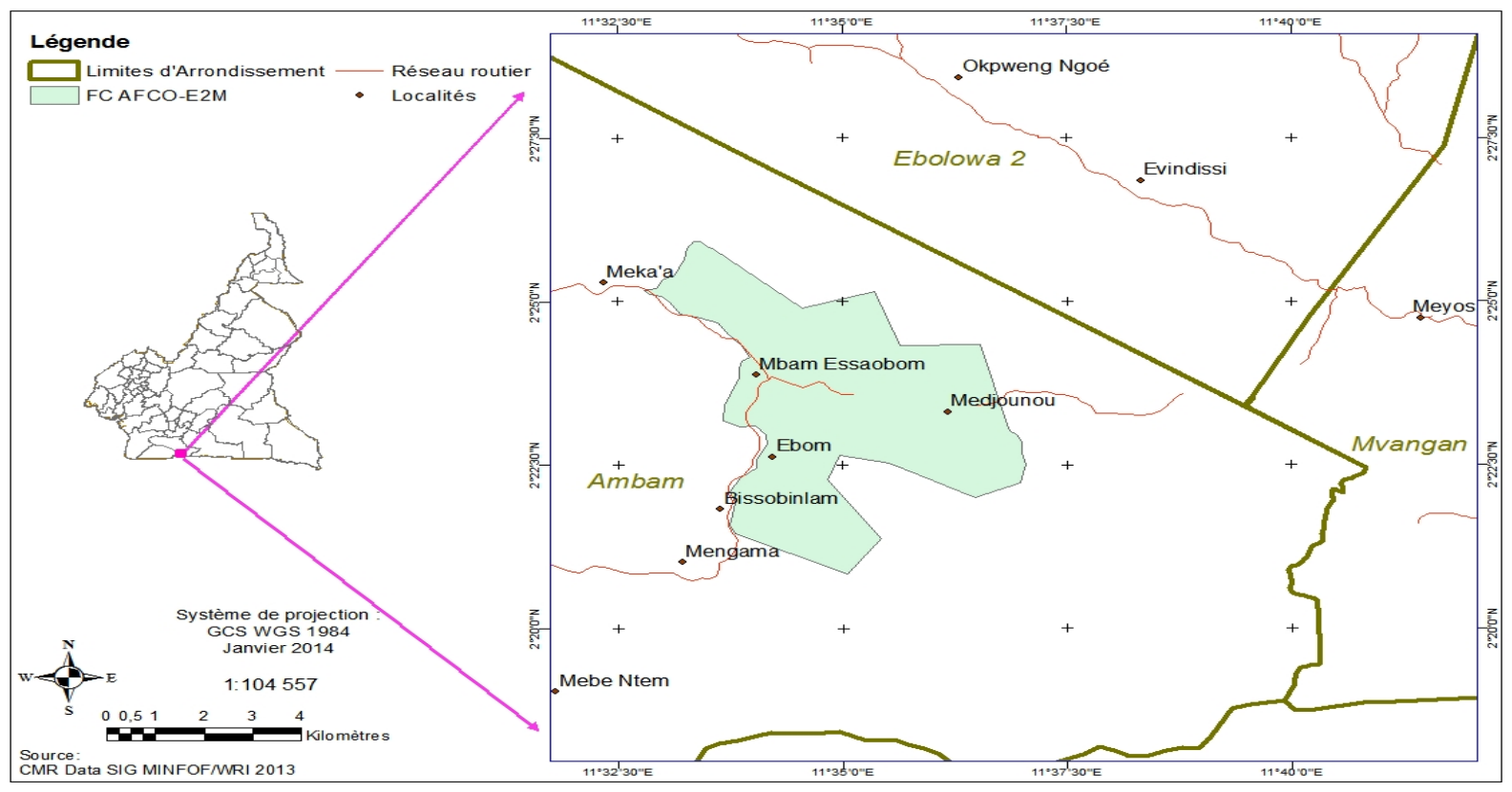

Figure 1. Location map of the AFCOE2M Community forest (Mabe, 2013).

The climate is of the Guinean equatorial type (bimodal rainfall) with four seasons: a long rainy season (mid-August to mid-November), a long dry season (mid-November to mid-March), a short rainy season (mid-March to mid-June), and a short dry season (mid-June to mid-August). The average annual rainfall varies 
from $1600 \mathrm{~mm}$ to $1700 \mathrm{~mm}$, meanwhile average temperature ranges between $23.8^{\circ} \mathrm{C}$ and $25.3^{\circ} \mathrm{C}$, with an average of $24.5^{\circ} \mathrm{C}$. AFCOE2M community forest is part of the tropical rain forest area and most particularly the rainforest zone of evergreen forest at low and medium altitudes (Gartlan, 1989). They contain many species of high economic value (Table 1).

Table 1. Some NTFPs of the AFCOE2M and their uses

\begin{tabular}{lll}
\hline Species & Part used & Use \\
\hline Afromomum melegueta & Seed & Ingredient for several traditional medicines \\
Afzelia bipindensis & Bark & Treatment of waist pain \\
Alchornea cordifolia & Bark & Treatment of diarrhea \\
Allanblackia floribunda & Seed & Aphrodisiac and treatment of stomach ache \\
Alstonia boonei. & Bark & Malaria treatment \\
Anonidium mannii & Fruit & Production of beverage \\
Baillonella toxisperma & Fruit and seed & Production of oil (seed) and treatment of \\
& & infertility in women (bark). \\
Cola acuminata & Seed & Direct consumption \\
Coula edulis & Seed & Direct consumption \\
Dacryodes edulis & Fruit & Direct consumption \\
Dacryodes macrophylla & Fruit & Juice fabrication. \\
Drypetes grossweileri & Bark & Aphrodisiac \\
Annikia chlorantha & Bark & Filaria and malaria treatment \\
Entandrophragma cylindricum & Bark & Treatment of anaemia \\
Entandrophragma utile & Bark & Facilitates expansion of the cervix during childbirth \\
Fagara hertzii & Seed & Spice \\
Garcinia kola & Bark and & Additive in palm wine (bark) and direct consumption (seed) \\
& seed & \\
Guarrea cedrata & Seed & Cure for back ache \\
Guibourtia tessmannii & Seed & Cleaning of genital tract and protection against witches \\
Harungana madagascariensis & Bark & Cleaning genital tract \\
Hylodendron gabunense & Fruit & Consumption \\
Irvingia gabonensis & Fruit & Spices for sauce. \\
Mammea africana & Bark & Cures sexual weakness \\
Myrianthus arboreus & Fruit & Production of beverage \\
Nauclea diderrichii & Seed & Treatment of sexual weakness \\
Pachypodanthium staudtii & Seed & Eliminates head lice \\
Picralima nitida & Bark & Malaria treatment \\
Piptadeniastrum africanum & Bark & Treatment of sexual weakness \\
Pterocarpus soyauii & Bark & Treatment of anaemia \\
Raphia & Stem & Construction of thatch houses and furniture production \\
Trichoscypha acuminata & Fruit & Production of beverage \\
Trichoscypha arborea & Fruit & Production of beverage \\
\hline & & \\
& & \\
& &
\end{tabular}

\subsection{Data Collection}

Data were collected through literature reviews, interviews with different actors including the local population, administrative officials and some local Non-Governmental Organizations (NGOs) present in the locality, as well as direct observation. Each respondent had to cite the plants used for pre-defined usage categories including food and medicinal purposes. Plants considered as food were those collected from the wild and eaten directly as fruits, used for seasoning as spices or leafy plants used as vegetables or for packaging. Those considered as medicine were plants frequently used within communities to treat common ailments like malaria, cough, diarrhea, headache, intestinal worms, etc. Note was taken of different land use types (crop field, cocoa agroforest, fallow and virgin forest) within the community forest from which NTFPs were collected and used by the local communities. The goal was to evaluate the contribution of NTFPs to the socioeconomic well-being of the population.

Data were analyzed using SPSS for means and percentages and the SAS software for the generalized linear model and Duncan test for the separation of means at the level of $\alpha=5 \%$. 


\section{Results}

\subsection{Identification of NTFPs used by the Communities}

One hundred and twenty five (125) people were interviewed and represented as follows: 53\% of women and $47 \%$ men. Forty seven (47) percent of respondents were in the 20 to 30 years age range, $40 \%$ in the 31 to 50 years age range and $13 \%$ of respondents were over 50 years old (men and women). Respondents varied with respect to occupation and consisted of farmers (66\%), farmers/traders (13\%), farmers/hair dressers (7\%), seamstress (7\%) and students (7\%). Fifty two (52) plant species were recorded for the two usage categories.

Table 2. List of plants identified in the villages according to the usage categories

\begin{tabular}{|c|c|c|c|c|}
\hline \multirow[t]{2}{*}{ Scientific names } & \multirow[t]{2}{*}{ Family } & \multirow[t]{2}{*}{ Local names } & \multicolumn{2}{|l|}{ Usage } \\
\hline & & & Nutritional plants & Medicinal Plants \\
\hline Aframoтит melegueta & Zingiberaceae & ndong & & + \\
\hline Allanblackia floribunda & Clusiaceae & nsangom & & + \\
\hline Alstonia boonei & Apocynaceae & ekouk & & + \\
\hline Aningeria robusta & Sapotaceae & Abam & + & + \\
\hline Annikia chlorantha & Annonaceae & Nfo'o & & + \\
\hline Anonidium mannii & Annonaceae & ebom & + & \\
\hline Antrocaryon klaineanum & Anarcadiaceae & ozakon & + & + \\
\hline Baillonella toxisperma & Sapotaceae & adjap & + & + \\
\hline Ceiba pentandra & Bombacaceae & edoum & & + \\
\hline Cola nitida & Sterculiaceae & kola & + & + \\
\hline Cola pachycarpa & Sterculiaceae & evoy & + & \\
\hline Coula edulis & Olacaceae & ewome & + & + \\
\hline Dacryodes edulis & Burseraceae & Sa'a & + & + \\
\hline Dacryodes macrophylla & Burseraceae & atom & + & + \\
\hline Elaeis guineensis & Palmaceae & Ikan & + & \\
\hline Erythropleum ivorensis & Caesalpiniaceae & Elone & & + \\
\hline Garcinia kola & Clusiaceae & Onien & + & + \\
\hline Garcinia lucida & Clusiaceae & essok & + & + \\
\hline Gnetum africanum & Gnetaceae & okok & + & \\
\hline Guibourtia tessmannii & Caesalpiniaceae & essinga & & + \\
\hline Irvingia gabonensis & Irvingiaceae & Ndo’o & + & + \\
\hline Maranthaceae & Maranthaceae & Akuen & + & \\
\hline Myrianthus arboreus & Cercopiaceae & Egokon & + & + \\
\hline Pachypodanthium staudtii & Annonaceae & ntome & & + \\
\hline Pentaclethra macrophylla & Mimosaceae & Ebaye & + & + \\
\hline Petersianthus macrocarpus & Lecythidaceae & Abwuing & & + \\
\hline Picralima nitida & Apocynaceae & ebam & & + \\
\hline Pipper guineense & Piperaceae & poivre noir & + & \\
\hline Pycnanthus angolensis & Myristicaceae & eten & & + \\
\hline Ricinodendron heudelotii & Euphorbiaceae & njansang & + & \\
\hline Scorodopheulus zenkeri & Caesalpiniaceae & Olong & + & \\
\hline Tetrapleura tetraptera & Mimosaceae & Saka & + & \\
\hline Trichoscypha acuminata & Anarcadiaceae & mvout & + & \\
\hline Trichoscypha arborea & Anarcadiaceae & ngong & + & \\
\hline Voancaga africana & Apocynaceae & obatom & + & + \\
\hline Terminalia superba & Combretaceae & Akom & & + \\
\hline Xylopia aethiopica & Annonaceae & Oyang & + & \\
\hline Piptadeniastrum africanum & Caesalpiniaceae & Edza & + & \\
\hline
\end{tabular}

N.B: $+=$ presence

\subsection{Usage of NTFPs}

Out of the 52 species recorded, 14 were strictly medicinal, among which are Alstonia boonei, Picralima nitida, Annikia chlorantha and Ceiba pentandra while 12 were strictly used for nutrition such as Irvingia gabonensis, Ricinodendron heudelotii, Gnetum africanum and Annonidium mannii. The results revealed that plant parts used 
for consumption consisted of $68 \%$ fruits, $20 \%$ seeds, $5 \%$ bark, $4 \%$ roots, and $3 \%$ leaves while NTFPs used for medicinal purposes were mostly made of bark (70\%), seed $(16 \%)$, leaf $(7 \%)$, fruit $(5 \%)$ and roots $(2 \%)$.

A statistical analysis comparing NTFPs plant parts for both usage categories showed a significant difference $(\mathrm{P}$-value $=0.049)$ between those consumed as food, with seeds being most highly consumed unlike those used for medicinal purposes which showed no significant difference. (P-value $=0,86$ ).

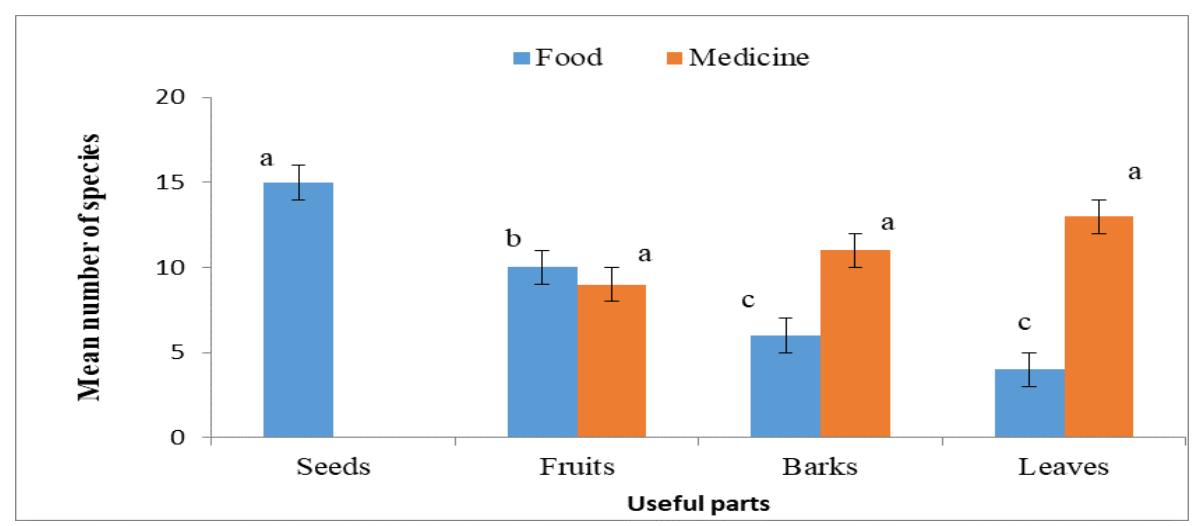

Figure 2. Parts of NTFP species used in each category

Means followed by the same letter are not significantly different at $5 \%$

With respect to land use types, it was observed that $38 \%, 29 \% 28 \%$ and $18 \%$ of collected NTFPs originated respectively from the virgin forest, fallows, cocoa agroforest and food crop fields. Thus, NTFPs used by the communities are predominantly collected from the virgin forest. The two usage categories varied according to their sources, with medicinal NTFPs mostly collected from the virgin forest and cocoa agroforest, while nutritional NTFPs were more frequently harvested from the cocoa agroforest and virgin forest in descending order, followed by fallow and cultivated field (Figure 3). There was a significant difference in the number of NTFP species used for food originating from different land use types $(\mathrm{P}$-value $=0.048)$ as well as between those used for medicinal purposes $(\mathrm{P}$-value $=0.012)$.

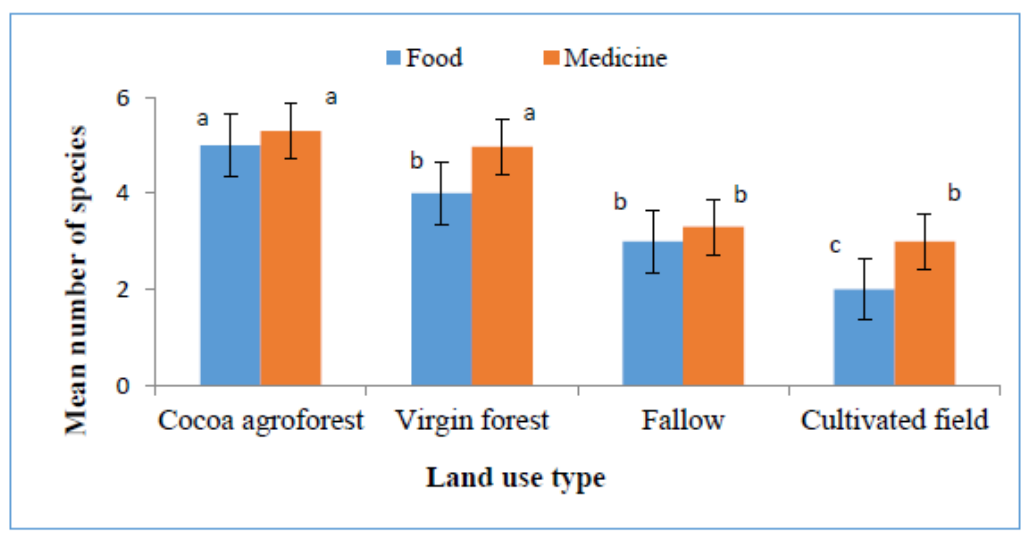

Figure 3. NTFP usage categories in each Land Use Type

Means followed by the same letters are not significantly different at $5 \%$ 
Figure 4 shows percent citation of common diseases in the study community.

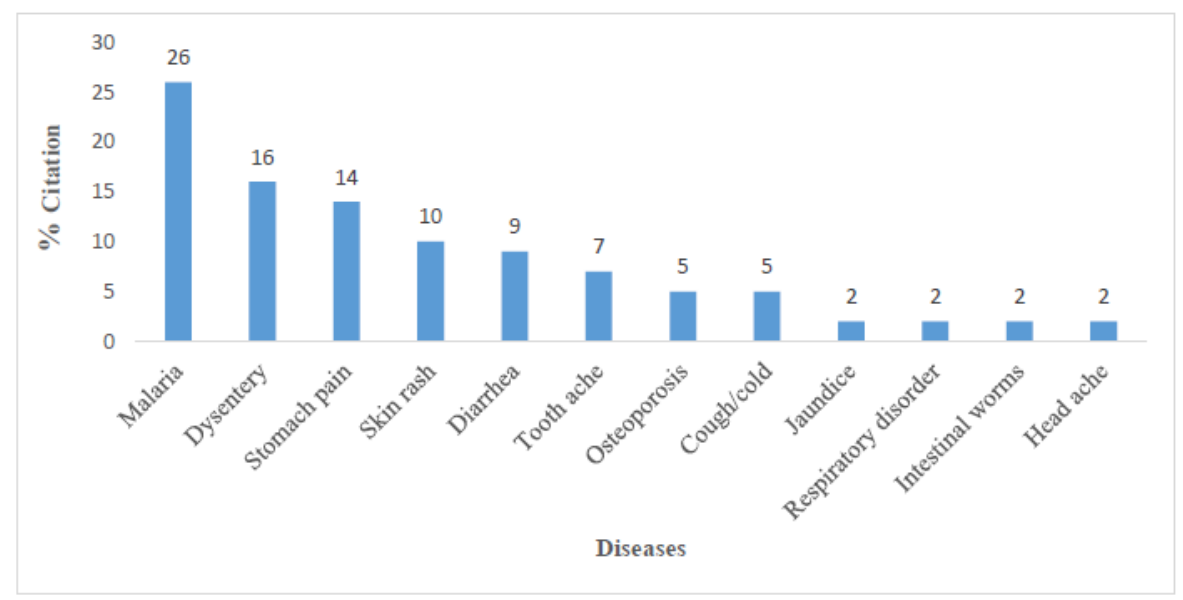

Figure 4. Recurrent diseases in the study community

The result revealed that malaria, dysentery and stomach pain are the most common ailments in the study community.

\section{Discussions}

The findings of this research showed that every sector of the community (women, men, youths and the elderly) participates in NTFPs collection. This is probably because NTFPs are freely collected, and as a matter of habit as people in most forest communities have been used to gathering these products from the forest over the years. This is in agreement with Ngansop et al. (2017) and Hirai (2014) who observed that indigenous people in forest communities in South East Cameroon gather NTFPs for their daily food supply as well as for medicinal purposes. More women $(53 \%)$ were involved in NTFPs collection than men $(47 \%)$ probably because they play the traditional role in daily food preparation in households and directly involved in taking care of the sick. Apart from agricultural products, NTFPs usually constitute a major source of income. However, with increasing monetary value of most NTFPs, men now participate in their collection and sometimes protect wildlings or plant them in cash crop (mostly cocoa) farms. A higher proportion of respondents (47\% for the 20 to 30 years age group and $40 \%$ for the 31 to 50 years range) belonged to the youthful and middle age groups probably because they still have physical strength to walk long distances to the forest and farms where NTFPs are collected. These age groups also have the responsibility to take care of the very young and very old, thus they make use of the benefits offered by NTFPs to meet their needs.

The outcome of this investigation revealed that NTFPs are mostly collected from the virgin forest and cocoa agroforest. This could be because NTFPs are likely to be more abundant in the forest which has undergone very little or no human intervention. When land is being cleared for cocoa cultivation, useful plants such as NTFP species are preserved, not only for the economic benefits they provide, but also for shade provision for the cocoa plant. A majority of people in most rural communities do not have stable sources of income such as formal jobs through which they can earn regular monthly salaries. Consequently, they collect, consume and sell NTFPs which are available at different periods of the year. This is in line with the findings of Nguetnamoum (2012) and Caspa et al. $(2015$; 2018) who reported that NTFP harvesting is the most important source of livelihood in most forest communities.

The fact that up to 52 plant species were cited for medicinal uses can be explained by the near absence of modern medical facilities in most rural communities due to their inaccessibility to urban centers. Medicinal plants are often obtained at no financial cost, unlike conventional medicines which are sometimes not affordable to local communities due to extreme poverty. Malaria was the most frequently cited disease, attesting to the fact that it is rampant in the area, as in other parts of Cameroon and the tropics. This is possibly due to the warm and moist conditions of the area that provide a favourable environment for the proliferation of mosquitoes which are vectors of the malaria parasite. Dysentery and stomach pain were the next important ailments cited. This is probably because of poor hygienic and sanitation conditions in such communities. Locals drink water from streams which are equally used for other activities, meaning one could be drinking downstream without knowing what activity took place upstream that might have contaminated the water. Consequently, there is a high 
prevalence of stomach disorder. As observed in this study, Betti et al. (2013) identified Alstonia boonei, Picralima nitida and Annikia chlorantha amongst many other plants used in Andom village in the East Region of Cameroon for the treatment of malaria. These plants are also well recognized in the literature for their activity against the malaria parasite (Betti, 2003; Idowu et al., 2010) and thus, gives credibility to the pharmacopoeia of the study community. The role of NTFPs (plants and animals) in the pharmacopoeia cannot be disputed. It is estimated that $80 \%$ of the world population primarily uses traditional medicines for their primary health care (FAO, 1997). This situation is very common in Africa and particularly in Central Africa where, humans have for centuries used plant or animal organs to heal themselves of some diseases. Plants for medicinal use in the Congo Basin are extremely numerous, hence, it is difficult to give an exact number of forest species used for medicinal purposes for each country. The general impression that emerges from people encountered during field visits is that almost all plants of the Congo Basin forests have therapeutic properties.

A significantly higher number of plant species had seeds and fruits as food source whereas those used for medicinal purposes mainly consisted of bark, leaves and roots. This could be due to the fact that naturally, the edible parts of most plants, and forest tree species in particular are fruits and seeds. The active ingredients for the different ailments concerned are certainly concentrated in plant parts extracted for medicinal purposes (leaves and bark) as shown in the results.

Tree bark is also used for other purposes such as additive in palm wine, the case of Garcinia kola bark. The latter resource is overexploited, therefore posing the problem of sustainability (Nguenang, 2010). Peters (1996) reported that commercial harvesting of NTFPs has a number of negative impacts, including a gradual reduction in the vigor of harvested plants, decreasing rates of seedling establishment of harvested species, potential disruption of local animal populations and nutrient loss from harvested material. For example, Guedje (2002) observed that stripping of the bark of Garcinia lucida, which is used as palm wine additive, resulted in a $74 \%$ mortality rate. The use of Scorodophloeus zenkeri bark as condiment is prevalent in the study community. However, according to community members, one must go far into the forest to obtain Scorodophloeus zenkeri bark of good quality. In our study site, the exploitation modes used were gathering and direct harvest. Similar to this research finding were the results of Loubelo (2012).

Indigenous food plants of the forests of the Congo Basin consumed regularly or occasionally are numerous. A survey conducted in Cameroon by Vivien and Faure (1996) revealed that there are more than 215 species of edible perennial fruit plants in the dense humid forest of Cameroon. The diversity of these species involves a variation in the phenology of production. Leafy vegetables are available all year while fruit production, taken in its diversity is spread over time. So at every time of the year, there is food in the forest to gather or harvest for food.

\section{Conclusion}

NTFPs play an important role in the medicinal and food habits of populations of the Medjounou, Mbam and Essaobam Ebozi II villages. However, from the results of the analysis it can be concluded that communities have enormous NTFPs potentials that are underexploited. Only a few NTFPs are sold regularly. Virgin forests and cocoa farms remain the most important places for the collection of NTFPs.

\section{Recommendations}

Collective action through the creation of common initiative groups in study villages can enhance NTFPs collection and valorization, hence livelihoods. Sustainable NTFPs harvesting practices should be adopted for a positive impact on resource conservation and management. This will enhance NTFPs quality and quantity as well as economic returns. NTFPs could also be planted on-farm in different agroforestry systems to ensure continuous availability of products and reduced pressure on the wild stock.

\section{References}

Aiyeloja, A. A., \& Ajewole, O. I. (2006). Non-timber forest products marketing in Nigeria: A case study of Osun state. Educational Research and Reviews, 1(2), 52-58.

Amang, M. J., Neudjo, R. P., Nwegueh, A., Caspa, R. G., Agodo, M. J. B., Foahom, B., \& Woin, N. (2015). Issues of non-timber forest products valorization in a community forest in South Cameroon. FOSAS international symposium, 11-12 November, Yaounde, Cameroon.

Angelsen, A., \& Wunder, S. (2003). Exploring the Forest-Poverty Link: Key concepts, issues and research implications. Centre for International Forestry Research: Bogor, Indonesia, p. 15-27.

Betti, J. L. (2003). Plantes utilisées pour soigner le paludisme dans la Réserve du Dja, Cameroun. Revue de 
Médecines et Pharmacopées Africaines, 17, 121-130.

Betti. J. L., Caspa. R. G., Ambara. J., \& Kourogue, R. L., (2013). Ethno-botanical study of plants used for treating malaria in a forest-savanna margin area, East Region, Cameroon. Global J Res. Med. Plants \& Indigen. Med., 2(10), 692-708.

Caspa, R. G., Tchouamo, I. R., Mate, M. J., \& Amang, M. J. (2018). Marketing Ricinodendron heudelotii kernels and Gnetum spp. leaves around Lobeke National Park, East Cameroon. Tropicultura, 36(3), 565-577.

Caspa, R. G., Tchouamo, I. R., Mate, M. J., Amang, M. J., \& Ngwa, M. N. (2015). The place of Irvingia gabonensis in village communities around the Lobeke National Park in Cameroon. Bois et Forêts des Tropiques, 324(2), 5-17. https://doi.org/10.19182/bft2015.324.a31262

Caspa, R. G., Tchouamo, I. R., Mate Mweru, J. P., \& Amang, M. J. (2014). The ecological status and uses of Ricinodendron heudelotii (Baill.) Pierre and Gnetum species around the Lobeke National Park in Cameroon. Agriculture, Forestry and Fisheries, 3(6), 469-480.

Ernst, C., Verheggben, A., Mayaux, P., Hansen, M., \& Defourny, P. (2010). Etat des forêts de l'Afrique Centrale: cartographie du couvert forestier et des changements du couvert forestier en Afrique centrale. Rapport d'évaluation. COMIFAC, 20.

Eyog, M. O., Ndoye, O., Kengue, J., \& Awono, A. (2006). Les Fruitiers Forestiers Comestibles du Cameroun. Cotonou, Bénin, IPGRI Regional Office for West and Central Africa, 204.

Food and Agriculture organization of the United Nations (1997). Medicinal plants for forest conservation and health care. Global Initiative For Traditional Systems (GIFTS) Of Health. Non-Wood Forest produc1 11, 158.

Gartlan, S. (1989). La conservation des ecosystemes forestiers du Cameroun. UICN, Gland, Suisse et Cambridge, UK.

Gomez-Baggethun, E., Corbera, E., \& Reyes-Garcia, V. (2013). Traditional ecological knowledge and global environmental change: research findings and policy implications. Ecol Soc, 18(4), 72. https://doi.org/10.5751/ES-06288-180472

Guedje, N. M. (2002). La gestion des populations d'arbres comme outil pour une exploitation durable des produits forestiers non-ligneux: l'exemple de Garcinia lucida (sud-Cameroun), (PhD Thesis). Tropenbos-Cameroon Series 5. Kribi: Tropenbos-Cameroon programme / Brussels: Université Libre de Bruxelles.

Hirai, M. (2014). Agricultural land use, collection and sale of non-timber forest products in the agroforest zone in Southeastern Cameroon. African Study Monographs, Suppl., 49, 169-202.

Hoare, A. L. (2007). The use of non-timber forest products in the Congo basin, constraints and opportunities. Retrieved from http:www.rainforestfoundationuk.org/files/Forest\%20Products\%20Low\%20PDF.pdf

Idowu, O. A., Soniran, O. T., Ajana, O., \& Aworinde, D. O. (2010). Ethnobotanical survey of antimalarial plants used in Ogun State, Southwest Nigeria. African Journal of Pharmacy and Pharmacology, 4(2), 055-060.

Ingram,V., Ndoye, O., Iponga, D. M., Tieguhong, J. C., \& Nasi, R. (2012). Non-timber forest products: contribution to national economy and strategies for sustainable management. In D. D., de Wasseige, C. de Marcken, P. Eba'a Atyi, R. Nasi \& R. Mayaux (Eds.), Les Forêts du Bassin du Congo, Etat des Forêts 2010 (pp. 58-62). Ph. Office des publications de l'Union Europeenne, Yaoundé, 137-156, 249. Workshop proceedings.

Johns, T., \& Sthapit, B. R. (2014). Biocultural diversity in the sustainability of developing country food systems. Food Nutr Bull, 25(2), 143-155. https://doi.org/10.1177/156482650402500207

Loubelo, E. (2012). Impact des Produits Forestiers Non Ligneux (PFNL) Sur L’économie des Ménages et la Sécurité Alimentaire: cas de la République Du Congo. Université Rennes 2, Ecole Doctorale «Sciences Humaines et Sociales », 260.

Mabe, M. N. (2013). Evaluation du niveau de vie des populations locales sur la base de l'utilisation des PFNL issus de leur forêt: cas de la forêt communautaire d'AFCOE2M à Ambam, Cameroun. Unpublished Professional Masters Thesis. University of Yaounde 1, Cameroon. I 47.

Ngansop, M. T., Sonwa, D. J., Fongnzossie, E. F., Biyé, E. H., Forbi, P. F., Takanori, O., \& Nkogmeneck, B. (2019). Identification of main non-timber forest products and related stakeholders in its value chain in the 
Gribe village of southeastern Cameroon. Retrieved from https://www.researchgate.net/publication/331950627

Nguenang, G. M., Fongnzossie, E., \& Nkongmeneck, B. A. (2010) Importance des forêts secondaires pour la collecte des plantes utiles chez les Badjoué de l'Est Cameroun. Tropicultura, 28(4), 238-245. https://doi.org/10.4314/ijbcs.v4i5.65539

Nguetnamoun, Z. (2012). Evaluation de la conformité légale en matière d'exploitation et d'aménagement forestiers au regard de L'APV/FLEGT : cas des forêts communautaires d'AFCOM. Mémoire de fin d'étude, Université de Yaoundé 1. p. 85.

Nkwatoh, A. F., Labode, P., Iyassa, S. M., Nkwatoh, F. W., Ndumbe, N. L., \& Ewane, M. E. (2010) Harvesting and marketing of Gnetum species (Engl) in Cameroon and Nigeria. Journal of Ecology and the Natural Environment, 2(9), 187-193.

Olaniyi, O. A., Akintonde, J. O., \& Adetumbi, S. I. (2013). Contribution of non-timber forest products to household food security among rural women in Iseyin Local Government Area of Oyo State, Nigeria. Research on Humanities and Social Sciences, 3(7), 41-49.

Peters, C. M. (1996). The ecology and management of non-timber forests resources. World Bank Technical Paper Number 322.Washington, DC: The World Bank. https://doi.org/10.1596/0-8213-3619-3

SAS version 9. 0, version for window.

SCBD. (2001). Sustainable management of non-timber forest resources. Technical Series No 6 , CDB, Montreal.

Shackleton, C., \& Shackleton, S. (2004). The importance of non-timber forest products in rural livelihood security and as safety nets: a review of evidence from South Africa, South Afr. J. Sci., 100, 658-664.

Shanley, P., Pierce, A. R., Laird, S. A., Binnquist, C. L., \& Guariguata, M. R. (2015). From lifelines to livelihoods: Non-timber Forest Products into the twenty-first century In L. Pancel \& M. Kohl (Eds.), Tropical Forestry Handbook. Springer-Verlag Berlin Heidelberg. https://doi.org/10.1007/978-3-642-41554-8_209-1

SPSS version 16, for Window, INC. (2007).

Tabuna, H. (2000). Évaluation des échanges des produits forestiers non ligneux entre l'Afrique subsaharienne et l'Europe. FAO, Accra, Ghana.

Tchoundjeu, Z., Degrande, A., Leakey, R. R. B., Nimino, G., Kemajou, E., Asaah, E., Facheux, C., Mbile, P., Mbosso, C., Sado, T., \& Tsobeng, A. (2010) Impacts of participatory tree domestication on farmer livelihoods in West and Central Africa. Forests, Trees and Livelihoods, 19, 217-234. https://doi.org/10.1080/14728028.2010.9752668

Termote, C., Van Damme, P., \& Dhed'a Djailo, B. (2010). Eating from the wild: Turumbu indigenous knowledge on non-cultivated edible plants, Tshopo District, DR Congo. Ecology of Food and Nutrition, 49(3), 173-207. https://doi.org/10.1080/03670241003766030

Van Andel, T. (2006). Non-timber forest products the value of wild plants. Agrodok-series 39, CTA, Wageningen.

Vivien, J., \& Faure, J.-J. (1996). Fruitiers sauvages d'Afrique (Espèces du Cameroun). Ministère Français de la Coopération et CTA. p. 416.

\section{Copyrights}

Copyright for this article is retained by the author(s), with first publication rights granted to the journal.

This is an open-access article distributed under the terms and conditions of the Creative Commons Attribution license (http://creativecommons.org/licenses/by/3.0/). 